\title{
MANAGING STAKEHOLDERS OF A TOURISM COMPANY
}

ANNA PRZYBYLSKA

\begin{tabular}{|c|c|}
\hline & $\begin{array}{l}\text { Adam Mickiewicz University } \\
\text { e-mail: anna.przybylska@amu.edu.pl }\end{array}$ \\
\hline $\begin{array}{l}\text { RECEIVED } \\
\text { ACCEPTED }\end{array}$ & $\begin{array}{l}11 \text { March } 2015 \\
9 \text { August } 2015\end{array}$ \\
\hline $\begin{array}{l}\text { JEL } \\
\text { CLASSIFICATION }\end{array}$ & M14, M31, M51 \\
\hline KEYWORDS & tourism company, stakeholders, matrix of relationships \\
\hline ABSTRACT & $\begin{array}{l}\text { The paper describes the possibilities of using the method of stakeholder analysis based on the example of } \\
\text { tourism companies. On the basis of the characterisation of particular stakeholder groups the hierarchy of impor- } \\
\text { tance was created which is a significant contribution to service company management. The analysis concerned } \\
\text { all aspects of the functioning of a tourism company: microenvironment, macroenvironment and competitive } \\
\text { environment. The picture obtained as a result of analysis forms the basis for further research into stakeholders } \\
\text { and defining a complex strategies of managing relationships among them. }\end{array}$ \\
\hline
\end{tabular}

\section{Introduction}

Economic globalisation and technological progress have introduced numerous changes to the way we function in the world in general. The changes also concern the manner in which companies function in the tourism market. At present companies no longer work merely to achieve their profit targets and their building cooperation with their environment is gaining significance. At present in order to function properly in the market, entrepreneurs 
have no choice but to engage in cooperation with their company's stakeholders. At present it is not even a fashion but a prerequisite for proper business management not only in tourism.

Because of the character of activities carried out by a tourism company and the great impact it has on business environment, the paper aims at determining the roles that particular stakeholders of a tourism company play in managing it. Particular groups of stakeholders show little diversification, which is why no specific kinds of tourism companies are discussed. The research results are comparable for both accommodation providers and travel agencies. They can also apply to other tourism and recreation enterprises.

The issue of changes introduced in the process of management as viewed by the stakeholders of a particular company has only recently been discussed in the literature. Interest in stakeholders is no longer typical of Western World entrepreneurs only. The topic has been examined both in papers published in the West (e.g. Clarkson, 1995; Preston, 1990) and in Poland, only a few years later. Based on his own experiences, Białas (2008) presents the problem of stakeholders participating in the strategic management of a public organisation. Work carried out by Łudzińska and Zdziarski (2013), who were the Polish pioneers in the field, is probably a more general example of the country's contribution to such research. The researchers analysed a group of 500 presidents of Poland's biggest companies with the aim to determining their expectations about the development of the enterprises that they were in charge of and isolating, in their opinion, the most crucial stakeholders whose support and cooperation may help the companies achieve their intended development strategy aiming at receiving outstanding results in the companies they run. However, other examples should be treated as case studies. A fairly detailed approach is presented by Kozina (2007), who highlights the possibility of developing negotiation methods by making use of the fact that the stakeholders involved in the process are able to carry out analysis. Bukowska (2008) conducts a fairly detailed analysis of stakeholders starting with identifying them and ending up with describing the role they play in corporate management. Ogrodnik and Mieszaniec (2010) pay attention to the novel method of mapping the stakeholders of a company based on a case study of a mining enterprise. By describing how society influences various issues, Bęben, Marcinkowski and Papis (2014) assess the role that stakeholders play in building off-shore wind farms. Such an approach both raises the significance of this manner of management process and proves its legitimacy.

The methodology of the study stems from accepting assumptions that have been widely discussed in the literature (Kafel, 2000; Johnson, Scholes, 1999; Obłój, 2007 et al.). All the presented approaches explicitly isolate the same mapping stages which include stakeholders' identification and characteristics, the determination of relationships between stakeholders and companies and, finally, the assessment of the influence that stakeholders have on an enterprise. The analysis above requires using selected techniques that indicate the presence of a relationship between stakeholders and an organisation. The most important techniques should include a map of stakeholders, stakeholders, a matrix of relationships among strategic stakeholders and analysis of key stakeholders (Lisiński, 2004). Two techniques of stakeholder analysis were selected for the sake of the study: establishing key profiles of strategic stakeholders and a matrix of relationships among strategic stakeholders, which also enabled a more complex data analysis. 


\section{Notion, aim and scope of using stakeholdep analysis}

Stakeholder analysis, which is also often called analysis of partners, shareholders, supporters and actors, is one of the strategic analysis methods and is used to examine the external environment of a company as its strategy is being developed. Its essence is about determining and then looking into an organisation's strategic partners (Lisiński, 2004). As part of the aforementioned approach stakeholders' expectations and behaviours are explained and analysed and the same is done for the relationships among them, their attitude to the company as well as directions and possibilities of them making a company change its aims, functioning and efficiency. Therefore the method aims at identifying and analysing the kind and scope of the ability on the part of various interest groups to influence a particular company's strategy. The objective of the method is not only to isolate groups, businesses or institutions which are the organisation's strategic partners and to determine the type of a relationship between the business and its partners, but also to identify instruments or decisions they use to influence or to intend to influence the organisation (Lisiński, 2004). The scope of analysis of the term "stakeholder" is always strictly related to a researcher's interpretation of the word and the determination of the essence of relationships among them with reference to a specific company (Freeman, 1984).

The stakeholder theory itself describes the expectations of a company's internal, external and competitive environments from the perspective of individuals and groups that represent them. The term "stakeholders" has appeared in the English-language literature as a response to the word "shareholders". In the Polish literature it is translated as "interest groups" or "strategic supporters" of an organisation. The term "stakeholders" was finally accepted in the early 1990s. and is now in wide use (Łudzińska, Zdziarski, 2013). Generally speaking, stakeholders are identifiable individuals or groups that may have impact on an organisation achieving its intended goals or that may be influenced by the process of a company realising its objectives. In reality, theoreticians and practitioners still disagree as to who is and who is not a stakeholder and what real or potential influence he or she has on an organisation. According to a traditional approach, stakeholders can be divided into internal (e.g. employees, management board) and external (e.g. customers, suppliers) (Carroll, Buchholtz, 2009; Donaldson, Preston, 1995; Pakulska, Poniatowska-Jaksch, 2009). A completely different way of classifying stakeholders is to divide them into primary and secondary. Their goals are complimentary, rather than competitive (Freeman, 1984; Magness, 2008).

\section{Identififying the stakeholders of a tourism company}

In order to identify the stakeholders of a tourism company first it must be understood who stakeholders are, or who are the groups or individuals that can influence an organisation or are interested in the goals it strives to achieve. More specifically, various interest groups can be divided according to the nature of activities that a particular company carries out. However, a universal approach is adopted in the discussion below, which makes it possible to isolate major interest groups characteristic of all companies with a similar impact (Figure 1). 


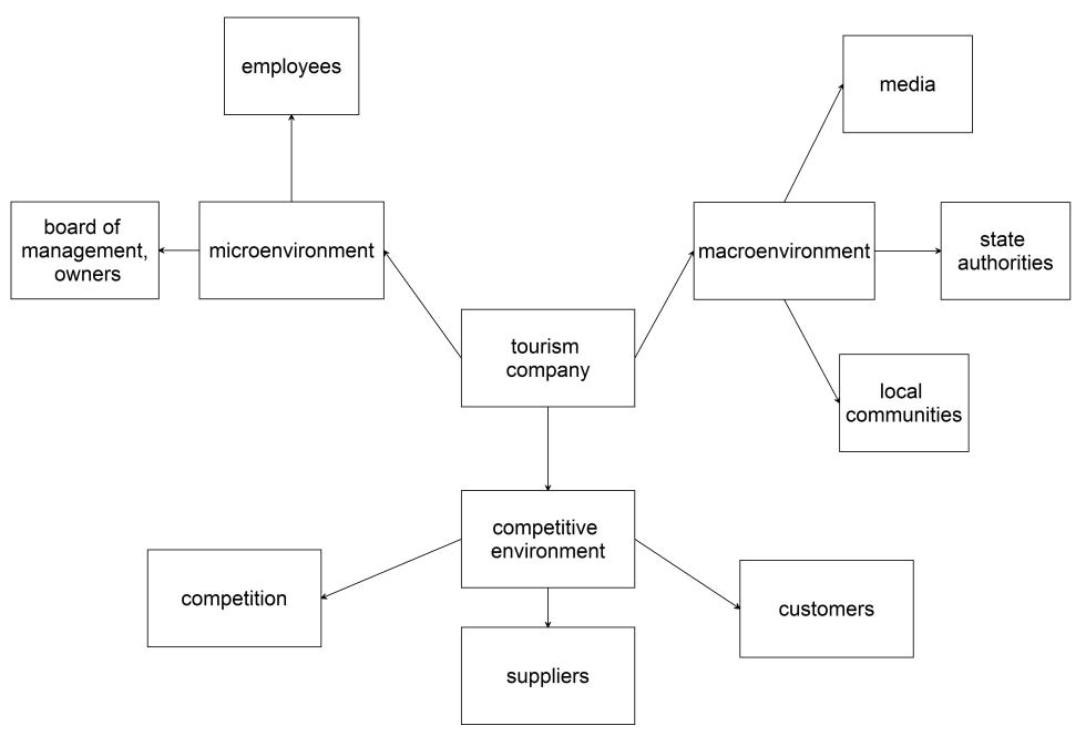

Figure 1. Identifying stakeholders of a tourism company

Source: own elaboration.

The isolation presented above stemmed first of all from the characterisation of the relationships among stakeholders and the relationship between a tourism company and its stakeholder and considered the most important features:

- a relationship between a company and its partner is usually mutual, but it does not have to be sustainable,

- a company may be dependent on its partner who creates the foundation of its existence and survival; he or she has power over it,

- partners depend on a company both morally and legally and they remain under its influence;

- the strength of the relationship between a company and its partners are subject to change over time,

- relationships between a company and its partner are contractual and strive to establish balance,

- these relationships are based on lawful demands and expectations and must aim at meeting or reducing them (Kafel, 2000).

\section{Stakeholder diagnosis}

\section{Macroenvironment - state authorities}

Tourism policy is a process of guiding tourism development in which the coordination of activities carried out by various institutions operating in various sectors of economy is of considerable importance. The role of the coordinator of all sectors influencing tourism development is played by the state. As part of the policy it conducts, it must consider not only multiple functions of tourism and interests of various entities in the tourism market, but also the fact that its policy is now a significant element in international relations. However, changes such as the economic crisis, increasing globalisation and regulations of tourism organisations shape a country's tourism policy which impacts the development of tourism-related businesses. 


\section{Macroenvironment - Iocal community}

The location of any company always impacts its immediate environment, especially given that tourism itself has manifold influences not only on the surrounding area, but also, or even more so, on the local community. Apart from the basic influence that tourism has on its surrounding, i.e. boosting the regional infrastructure by for example good access roads, water and sewage networks, healthcare services, establishing communication with bigger centres, there is also an indirect impact often stemming from the kind of a company. Employment opportunities are crucial, as these mean raising living standards. A particular area is developed and its attractiveness is raised, which creates a perpetuum mobile, because such activities spur local community into action and one initiative leads to another. More and more small enterprises are created to make rest areas more attractive to tourists. The awareness of a company's influence and the necessity to communicate with local community confirms the existence of one of the recent most important corporate management strategies, namely corporate social responsibility, CSR. CSR is implemented by small and medium-sized enterprises in the tourism market and creates a lot of benefits for both the local community in which a tourism company is located and the company itself. This stems partly from the function of tourism as a phenomenon.

\section{Macroenvironment - (social) media}

For a few years now it has been undoubtedly observed that social media have not only impacted various kinds of social groups, but also business environment. Social media offer countless possibilities of communicating information, which explains why they enjoy considerable popularity in various business fields. The tourism industry is not lagging behind in this area and has recently started using social media for marketing activities. The significance of this information source as a communication platform with a potential client has not been raised solely for business. According to a World Travel Market 2011 Industry report, tourists are increasingly turning to social media as a key information source for rest places. UK research shows that information found in social media services or blogs influence the choices of $40 \%$ of respondents. When it comes to the tourism industry, Trip Advisor remains the dominant brand and is used by two thirds of social media users. In addition, there has been a rise in the number of holiday destination decisions as a result of information found in the Internet. An increase in the popularity of such social media platforms as Facebook, Groupon and Youtube has rendered the previous ways of promoting the tourist industry ineffective. At present consumers' and of course employers' awareness is heightening with the latter recognising the importance of social media and the fact that their business' online presence is crucial to their existence. Hence the changes have also concerned spending on online marketing, which seems to have recently become the most important communication channel between a customer and a service provider.

\section{Competitive environment - Customers}

Customers are the most significant impact group among all stakeholders, because they form the basis for the functioning of service companies. In a responsible approach to cooperation with impact groups building relationships with customers systematically and efficiently is a source of competitive advantage and measurable profits. First of all adequate relationships are all about communicating with customers and identifying their needs and expectations, promoting ethical attitudes and ensuring the highest quality of services. Good relationships with customers are key to succeeding in the market. They allow a company to function efficiently and ensure the satisfaction of consumers 
who have trust in the business. The nature of the functioning of a tourism company ensures that customers become an integral part of a company, and the entrepreneur does not only wish to stay in touch with them, but he or she is forced to do so, because this is what his or her company's development hinges on.

\section{Competitive environment - competition}

The existence of such considerable competition in the tourism market should be perceived as an opportunity which allows adapting a tourist offer to the changing expectations of potential tourists. Competition within the tourist market was observed as early as during the post-war period (1955-1970) (Weiermair, 1998), when the fishery and agricultural sectors began to change trade and at the same time perform a tourist function. Competition within the tourism market concerns not only tourism companies, but also reception areas. In the globalising world traditional (mainly European) tourist areas with small and medium-sized enterprises and independent companies (operating outside networks) do not always cope with new challenges, are not capable of organising full-scale activity or ensuring the adequate scope of promotion and competitiveness (Kachniewska, 2012).

\section{Competitive environment - suppliers}

A team of suppliers is quite large when it comes to the functioning of tourism companies. Major suppliers include service providers, suppliers of raw materials, providers of finished goods, outsourcing specialists, distributors, vendors and all cooperating entities, etc. Complying with the principles of sufficient supply management in a company, they create well-organised and individual supply chains. These chains are formed by any entities providing a company with products and services indispensable for meeting the needs of consumers by supplying them with final goods.

To be more precise, it is possible to identify suppliers and distributors as various links within a supply chain, whereby two of them are of paramount importance. First-grade suppliers are entities that provide services directly to tourists (e.g. accommodation providers). Second-grade suppliers are those offering their services to first-grade suppliers. Tourists do not usually have direct contact with second-grade suppliers (e.g. food producers). In addition, one must not forget about an important function performed by tour operators, sending agencies, carriers and finally customers, who are the last link in a supply chain.

\section{Microenvironment - a company's management board/owners}

The way a tourism company is managed is always dependent on its owners' point of view. Building the value of a company is one of the basic strategies of running a business and incorporating management processes has become indispensable for putting the strategy into action in recent years. As ensuring an increase in the value of a company is not only crucial to its owner, but also helps meet the needs of other stakeholder groups (employees and consumers), it seems important to start dialogue with them and continue to seek information about their needs.

\section{Microenvironment - employees}

Employees are an integral part of each company. They are the most important link among internal stakeholders. Adequate communication between employees and the company they work for contributes to success to a large extent, guaranteeing a competitive and stable position in the market. A well-thought-out dialogue with 
its employees not only allows a company to function efficiently, but also helps the employees realize their own individual (often life) goals, acquire new skills, qualifications, competences and knowledge. In tourism the number of those employed in a company is also of substantial importance. One can speak of microcompanies (e.g. a travel agent) and macrocompanies (e.g. a chain hotel) depending on the nature of their business activities. Of course this has something to do with a situation that in the hotel industry even the largest hotels (considering the number of employees) are relatively small if they are to be compared to industrial companies or certain types of service companies. This means it is virtually impossible to achieve economies of scale in the industry. Regardless of the size it is an employee that is the basic link between his or her company and a consumer and the way that its employees are perceived by tourists has an effect on how they perceive the company itself. As a matter of fact it might be said that a satisfied employee means a happy customer.

\section{Determing the hierachy of importance of stakeholders}

Stakeholders can be divided into four groups based on the Johnson and Scholes matrix (quoted from Ogrodnik, 2010):

- key stakeholders - very interested in a company's situation and influencing it to a great extent (group 1),

- stakeholders very interested in a company's situation, but influencing it to little extent (group 2),

- stakeholders with a considerable impact on a company, but not interested in its situation (group 3),

- stakeholders uninterested in the situation of a company and influencing it to a negligible extent.

Since analysis concerned the key stakeholders of a tourism company, group four did not have any stakeholders.

The other groups included:

Group 1: customers, suppliers, management board/owner, employees.

Group 2: competition, local community.

Group 3: local communities, media.

\section{Identifying the relationships hetween stakeholders and a tourism company}

The relationship between stakeholders and a company was determined using influence matrix. Based on the previous stage, all stakeholders in groups 1-3 were placed in the influence matrix and then the nature of the relationship was defined. The strength of the influence of a particular relationship was put on a number scale:

0 - no influence,

1 - small influence usually with no further consequences,

2 - average influence occasionally causing further consequences,

3 - average influence causing further consequences,

4 - significant influence causing further consequences,

5 - quite considerable influence with an effect on activities.

The strength of the relationship was determined based on surveys conducted among 97 companies in the Wielkopolskie voivodeship. After the strength of the relationship was identified in the influence matrix, figures were added up in the matrix columns and rows (last column/last row) (Table 1). 
Table 1. Matrix of relationships and influences among the key stakeholders of a tourism company

\begin{tabular}{|c|c|c|c|c|c|c|c|c|c|}
\hline & Customers & Suppliers & Competition & Employees & $\begin{array}{c}\text { Management } \\
\text { board }\end{array}$ & $\begin{array}{c}\text { Local } \\
\text { community }\end{array}$ & $\begin{array}{c}\text { Local } \\
\text { authorities }\end{array}$ & Media & INFLUENCE \\
\hline Customers & & 3 & 4 & 4 & 3 & 2 & 1 & 3 & 20 \\
\hline Suppliers & 2 & & 4 & 2 & 4 & 3 & 2 & 2 & 19 \\
\hline Competition & 4 & 3 & & 2 & 4 & 3 & 3 & 4 & 23 \\
\hline Employees & 3 & 1 & 3 & & 5 & 2 & 2 & 4 & 20 \\
\hline Management board & 1 & 1 & 2 & 3 & & 2 & 3 & 4 & 16 \\
\hline Local community & 1 & 2 & 2 & 2 & 1 & & 3 & 2 & 13 \\
\hline Local authorities & 1 & 2 & 2 & 3 & 1 & 3 & & 3 & 15 \\
\hline Media & 2 & 1 & 2 & 3 & 1 & 3 & 4 & & 16 \\
\hline INFLUENCE & 14 & 14 & 20 & 20 & 22 & 18 & 19 & 23 & \\
\hline
\end{tabular}

Source: own elaboration.

Adding up the figures in the matrix columns and rows enabled obtaining results which could be interpreted twofold:

1. The general strength of the influence of stakeholders on a tourism company (the influence was calculated by adding up the figures in rows).

2. The dependence of one stakeholders on the others (the influence was calculated by adding up the figures in columns).

Based on that the following conclusions can be drawn:

1. Competition is of the greatest importance in the matrix of the strength of influence on a tourism company. It happens so for several reasons. Major ones include a high level of competitiveness among tourism companies, especially in urban centres, constant observation of a competitor's tourist product both on the part of the consumer and a tourism company, the strength of the relationship between our competitor and the media, local authorities and suppliers comparable to ours.

2. It is also worth noting that employees and customers are groups with a comparable strength of influence right behind competition. The situation mainly stems from two causes. First, the legitimacy behind the functioning of each tourism company is derived from the presence of customers. However, as shown in the analysis of stakeholder groups presented in the earlier stage, client satisfaction can often be linked to the way employees perform their duties and their competences.

3. Additionally, media are a stakeholder group characterised by the greatest connection with all the other groups, which hardly comes as a surprise. This of course comes from the fact that media influence all walks of life. It is media that are most often used for promoting a company, but it is also media which are mainly responsible for publicising negative stories about a particular business, which often leads to its collapse.

\section{Conclusions}

A tourism company is a service company, which means at the same time that it is largely dependent on maintaining optimal relationships with its stakeholders. As a result, a need arises of not only maintaining 
communication with them, but simply managing them, of course considering their hierarchy of importance. Companies seeking competitive edge are constantly forced to change or simply adapt ways of management to the changing social and economic environment. Constant communication with various stakeholder groups allows recognising their needs and expectations, and, consequently reacting in a timely manner as far as tourist services are concerned. Considering the needs of stakeholders and constant communication with them are essential to win competitive advantage. The analysis of stakeholders used certainly has further significance and in addition allows conducting further analyses which will make it possible to create a complex policy of conduct with regard to particular stakeholder groups. The acceptance of such a strategy enables using the potential of particular stakeholders to the full.

\section{References}

Beben, R., Marcinkowski, T. \& Papis, O. (2014). Analiza interesariuszy w projektach budowy morskich farm wiatrowych. Zarządzanie i Finanse. Journal of Management and Finance, 12 (3/1).

Bukowska, U. (2008). Proces zarządzania interesariuszami. Zeszyty Naukowe Uniwersytetu ekonomicznego w Krakowie, 784.

Carroll, A.B., Buchholtz, A.K. (2009). Business \& Society: Ethics \& Stakeholder Management. 7th ed. Mason, OH: Cengage Publishing Company.

Clarkson, M.B.E. (1995). A Stakeholder Framework for Analyzing and Evaluating Corporate Social Performance. Academy of Management Review, 20 (1): 92-117.

Donaldson, T., Preston, L.E. (1995). The Stakeholder Theory of the Corporation: Concepts, Evidence and Implications. Academy of Management Review, 20 (1).

Freeman, E.R. (1984). Strategic Management. A Stakeholder Approach. Boston: Pittman.

Johnson, G., Scholes, K. (1999). Exploring Corporate Strategy. Text and Cases. London: Prentice Hall.

Kachniewska, M. (2012). Wpływ korporacji transnarodowych na kształt współczesnego rynku turystycznego. In: Międzynarodowe stosunki gospodarcze - internacjonalizacja i konkurencyjność narodowa. Ed. T. Sporek. Zeszyty Naukowe Wydziałowe Uniwersytetu Ekonomicznego w Katowicach.

Kafel, T. (2000). Metodologiczne aspekty analizy mikrootoczenia organizacji. Zeszyty Naukowe Akademii Ekonomicznej w Krakowie, 554.

Kozina, A. (2007). Analiza interesariuszy w planowaniu negocjacji. Wałbrzych: WWSZiP.

Lisiński, M. (2004). Metody planowania strategicznego. Warszawa: PWE.

Ludzinska, K., Zdziarski, M. (2013). Interesariusze w opinii prezesów zarządów polskich przedsiębiorstw. Kwartalnik Nauk o Przedsiębiorstwie, 2

Magness, V. (2008). Who are the Stakeholders Now? An Empirical Examination of the Mitchell, Agle, and Wood Theory of Stakeholder Salience. Journal of Business Ethics.

Obłoj, K. (2007). Strategia organizacji. Poszukiwaniu trwałej przewagi konkurencyjnej. Warszawa: PWE.

Ogrodnik, M., Mieszaniec, J. (2010). Metoda analizy interesariuszy jako innowacyjna koncepcja w zarządzaniu przedsiębiorstwem górniczym. In: Komputerowo zintegrowane zarządzanie. Oficyna Wydawnicza Polskiego Towarzystwa Zarządzania Produkcja.

Pakulska, T., Poniatowska-Jaksch, M. (2009). Przedsiębiorstwo a otoczenie w warunkach globalizacji. In: Strategie przedsiębiorstw wobec zrównoważonego rozwoju. Warszawa: SGH.

Weiermair, K. (1998), Entrepreneurship and Small Business: The Case of the Entrepreneurial SME in Tourism. In: Creating Jobs: New Demand on SMEs \& Their Support Partners. Proceedings, 2: 501-514.

Cite this article aS: Przybylska, A. (2015). Managing stakeholders of a tourism company. Szczecin University Scientific Journal, No. 883. Service Management, 16 (2): 119-127. 
